\title{
Gambaran Kejadian Infeksi Bayi Baru Lahir di Bagian Perinatologi RSUP Dr.M.Djamil Padang Tahun 2012
}

\author{
Irvina Meliya a ${ }^{\text {a }}$ Vetty Priscilla ${ }^{a}$ \\ ${ }^{\text {a} F a k u l t a s ~ K e p e r a w a t a n, ~ U n i v e r s i t a s ~ A n d a l a s ~}$
}

\begin{abstract}
Infection is one of the contributed factors of neonatal morbidity and mortality in the world. Infection in neonatal were divided into two groups. There were major infection (neonatal sepsis, meningitis, neonatal pneumonia, urinary tract infection, acute osteitis, neonatal tetanus) and minor infections (omphalitis, pemphigus neonatorum, ophthalmia neonatorum, moniliasis, stomatitis). The purpose of this study was to see description of the neonatal incidence infection in perinatology unit at Dr.M.Djamil Padang Hospital in 2012. The design was a descriptive study by using retrospective at the medical records department with a check list. The samples were 262 newborn. The results were analyzed by univariate and it showed that 78.6\% of babies was suffered from major infections. Based on the result, it is sugested to mother in order to pay attention to their health and their nutrition during pregnancy. So, it can reduce the preterm pregnancies, which is one of predisposition factors of infection. Thus, increasing precaution steps of infection to the newborn for the health personnel.
\end{abstract}

Key words: incidence of infection, the newborn, major infection

\begin{abstract}
Abstrak: Infeksi merupakan salah satu penyebab penting tingginya angka kesakitan dan kematian bayi baru lahir di seluruh dunia. Infeksi pada neonatus dibagi dalam dua golongan yaitu infeksi berat dan infeksi ringan. Tujuan penelitian ini adalah untuk mengetahui gambaran kejadian infeksi pada bayi baru lahir di bagian perinatologi RSUP Dr.M.Djamil Padang tahun 2012. Jenis penelitian ini adalah penelitian deskriptif dengan studi retrospektif dengan rekam medis. Sampel penelitian ini adalah 262 bayi baru lahir. Hasil penelitian ini menunjukkan, hampir seluruh $(78,6 \%)$ bayi mengalami infeksi berat, dan sebagian kecil $(21,4 \%)$ bayi mengalami infeksi ringan. Berdasarkan penelitian tersebut, Bagi ibu bayi dapat mengatur pola makan sehat dan bergizi dalam jenis dan jumlah yang cukup pada ibu untuk mempertahankan daya tahan tubuh sehingga terhindar dari penyakit infeksi. Selain itu disarankan kepada ibu untuk meningkatkan pengetahuan ibu tentang pentingnya pemeriksaan saat hamil (Antenatal Care) dan tentunya tenaga kesehatan harus meningkatkan perlindungan diri untyuk mencegah innfeksi pada bayi yang baru lahir.
\end{abstract}

Kata Kunci: Kejadian Infeksi, Bayi baru lahir, infeksi berat

\section{PENDAHULUAN}

Bayi baru lahir adalah bayi dari lahir sampai usia empat minggu, biasanya lahir pada usia kehamilan 38 minggu sampai 42 minggu (Wong, 2011). Bayi baru lahir harus memenuhi sejumlah tugas perkembangan untuk memperoleh dan mempertahankan eksistensi fisik secara terpisah dari ibunya.

Infeksi merupakan salah satu penyebab penting tingginya angka kesakitan dan kematian bayi baru lahir di seluruh dunia. World Health Organization memperkirakan 4 juta anak meninggal selama periode neonatal setiap tahunnya, terutama di negara berkembang dengan infeksi sebagai penyebab utama. Dalam buku ilmu kesehatan anak, 2007 dikatakan bahwa infeksi pada neonatus cepat sekali menjalar menjadi infeksi umum, sehingga gejala infeksi lokal tidak menonjol lagi. Walaupun demikian, diagnosis dini dapat ditegakkan kalau kita cukup waspada terhadap kelainan tingkah laku neonatus yang seringkali merupakan tanda permulaan infeksi umum. Neonatus, terutama BBLR yang dapat tetap hidup selama 72 jam pertama dan bayi tersebut tidak menderita penyakit atau kelainan kongenital tertentu, namun tiba-tiba tingkah 
lakunya berubah, hendaknya harus selalu diingat bahwa kelainan tersebut mungkin sekali disebabkan oleh infeksi (Hutchinson, 1972).

Beberapa gejala yang dapat disebutkan diantaranya ialah malas minum, gelisah, atau mungkin nampak letargis, frekuensi pernapasan menigkat, berat badan tiba-tiba turun, pergeraka kurang, muntah dan diare. Selain itu, dapat terjadi edema, sklerema, purpura atau perdarahan, ikterus, hematospenomegali dan kejang. Suhu tubuh dapat meninggi, normal, atau dapat pula kurang dari normal. Pada bayi BBLR seringkali terdapat hipotermia dan sklerema. Umumnya dapat dikatakan bila bayi itu "not doing well" kemungkinan besar menderita infeksi. Menurut berat ringannya, infeksi pada neonatus dapat dibagi dalam dua golongan yaitu infeksi berat dan infeksi ringan. Infeksi berat (major infection) seperti sepsis neonaorum, meningitis, pneumonia neonatal, infeksi traktus urinarius, osteitis akut, tetanus neonatorum. Infeksi ringan (minor infection) seperti infeksi umbilikus (omfalitis), pemfigus neonatorum, oftalmia neonatorum, moniliasis, dan stomatitis. (Buku ilmu kesehatan anak, 2007). Angka kematian bayi dengan sepsis neonatal 2-4 kali lebih tinggi pada bayi dengan berat lahir rendah. Dengan angka kematian 15-40 $\%$ pada sepsis neonatal awitan cepat (sekitar 2-30\% disebabkan oleh Streptokokus grup B [SGB]) dan 10-20\% pada sepsis neonatal awitan lambat (2\% disebabkan oleh SGB). Tinggi rendahnya angka kematian tergantung dari waktu timbulnya penyakit, penyebabnya, besar kecilnya bayi, beratnya penyakit dan tempat perawatannya.

Sepsis neonatorum adalah sindrom klinik penyakit sistemik, disertai bakteremia yang terjadi pada bayi dalam satu bulan pertama kehidupan. (Pusponegoro, 2000). Sepsis neonatorum adalah infeksi aliran darah yang bersifat invasif dan ditandai dengan ditemukannya bakteri dalam cairan tubuh seperti darah, sumsum tulang atau air kemih
(Aminullah,2008). Sepsis primer biasanya disebabkan: Streptokokus Grup B (GBS), kuman usus Gram negatif, terutama Escherisia coli, Listeria monocytogenes, Stafilokokus, Streptokokus lainnya (termasuk Enterokokus), kuman anaerob, dan Haemophilus influenzae. Sedangkan penyebab sepsis nosokomial adalah Stafilokokus (terutama Staphylococcus epidermidis), kuman Gram negatif (Pseudomonas, Klebsiella, Serratia, dan Proteus), dan jamur. (Pusponegoro, 2000).

\section{METODE}

Jenis penelitian ini adalah penelitian deskriptif yang merupakan suatu penelitian yang bertujuan untuk memberikan gambaran tentang realita pada obyek yang diteliti secara obyektif. Penelitian ini dilakukan di RSUP Dr.M.Djamil Padang. Waktu penelitian dimulai dari Oktober 2012 sampai April 2013. Pengambilan data awal dilakukan pada bulan Oktober 2012. Pengambilan data penelitian dilakukan pada tanggal 14- 18 Februari 2013.

Populasi dalam penelitian ini adalah seluruh data rekam medis bayi baru lahir yang mengalami infeksi yang dirawat di ruangan perinatologi mulai dari bulan Januari sampai Desember 2012. Kriteria inklusi dalam penelitian ini adalah data rekam medis semua bayi baru lahir dengan diagnosis penyakit infeksi dengan data rekam medis lengkap. Kriteria eksklusi dari penelitian ini adalah data rekam medis bayi baru lahir yang mengalami infeksi nosokomial. Sampel pada penelitian ini diambil dengan metode total sampling. Sampel yang memenuhi kriteria yang dapat digunakan sebagai sampel yaitu sebanyak 262 data.

Pengumpulan data dilakukan dengan menggunakan lembar check list yang diisi di ruangan rekam medik. Lembar check list berisi karakteristik bayi baru lahir, karekteristik ibu, dan jenis penyakit infeksi. Karakteristik bayi terdiri dari nama, umur, jenis kelamin, berat badan lahir, dan prosedur invasif. Karakteristik ibu berisi usia gestasi ibu, lama ketuban pecah, serta 
warna dan bau ketuban. Dalam lembar check list juga terdapat cara keluar bayi, jenis infeksi, dan jenis penyakit infeksi yang dialami bayi.

\section{HASIL DAN PEMBAHASAN}

Table 1.

Distribusi Frekuensi Bayi Berdasarkan Karakteristik Bayi di Bagian Perinatologi RSUP Dr. M. Djamil Padang Tahun 2012 $(\mathrm{n}=262)$

\begin{tabular}{|c|l|ll|c|c|}
\hline $\begin{array}{c}\text { N } \\
\mathbf{0}\end{array}$ & $\begin{array}{c}\text { Karak- } \\
\text { teristik } \\
\text { Bayi }\end{array}$ & Kategori & F & \% \\
\hline 1. & Umur & $\bullet$ & $<8$ hari & 194 & 74 \\
& & $\bullet$ & $8-28$ hari & 68 & 26 \\
\hline 2. & Jenis & $\bullet$ & Laki-laki & 140 & 53,4 \\
& Kelami & $\bullet$ & Perempuan & 122 & 46,6 \\
& n & & & \\
\hline 3. & Berat & $\bullet$ & Normal & 166 & 63,4 \\
& Badan & $\bullet$ & BBLR & 60 & 22,9 \\
& Lahir & $\bullet$ & BBLSR & 29 & 11,1 \\
& & $\bullet$ & Makrosomia & 7 & 2,7 \\
\hline 4 & Prosedu & $\bullet$ & Ada & 81 & 30,9 \\
& r & $\bullet$ & Tidak ada & 181 & 69,1 \\
& Invasif & \multicolumn{4}{|l}{} \\
\hline
\end{tabular}

Berdasarkan tabel 2 dapat diketahui bahwa sebagian besar (74\%) bayi berumur dibawah 8 hari, sebagian besar bayi berjenis kelamin laki-laki (53,4\%), sebagian besar $(63,4 \%)$ bayi memiliki berat badan lahir normal, dan sebagian besar $(69,1 \%)$ bayi tidak dilakukan prosedur invasif.

Table 2.

Distribusi Frekuensi Ibu Berdasarkan Karakteristik bayi di Bagian Perinatologi RSUP Dr. M. Djamil Padang Tahun 2012 $(n=262)$

\begin{tabular}{|c|l|l|c|c|}
\hline No & $\begin{array}{c}\text { Karakteristik } \\
\text { Ibu }\end{array}$ & Kategori & F & \% \\
\hline 1 & Usia gestasi & Preterm & 84 & 32,1 \\
& ibu & Aterm & 160 & 61,1 \\
& & Posterm & 18 & 6,9 \\
\hline 2 & Lama ketuban & Normal & 218 & 83,2 \\
& pecah & KPD & 44 & 16,8 \\
\hline
\end{tabular}

\begin{tabular}{|c|l|l|c|c|}
\hline 3 & $\begin{array}{l}\text { Warna dan } \\
\text { bau ketuban }\end{array}$ & $\begin{array}{l}\text { Normal } \\
\text { Tidak } \\
\text { normal }\end{array}$ & $\begin{array}{c}173 \\
89\end{array}$ & 66 \\
34 \\
\hline
\end{tabular}

Berdasarkan tabel 3 di atas, dapat dilihat bahwa sebagian besar $(61,1 \%)$ bayi dengan usia gestasi aterm (27-42 minggu), hampir seluruh $(83,2 \%)$ bayi dengan lama ketuban pecah normal, dan sebagian besar $(66 \%)$ bayi dengan warna dan bau ketuban normal (tidak berwarna dan tidak berbau).

Tabel 3.

Distribusi Frekuensi Bayi Berdasarkan Jenis Penyakit Infeksi di Bagian Perinatologi RSUP Dr. M. Djamil Padang Tahun 2012

\begin{tabular}{|c|c|c|c|}
\hline No & $\begin{array}{l}\text { Jenis Penyakit } \\
\text { Infeksi }\end{array}$ & $\mathbf{F}$ & $\%$ \\
\hline $\mathbf{A}$ & \multicolumn{3}{|l|}{ Infeksi Berat } \\
\hline 1 & $\begin{array}{l}\text { Sepsis } \\
\text { neonatorum }\end{array}$ & 100 & 38,2 \\
\hline 2 & Meningitis & 13 & 5 \\
\hline 3 & $\begin{array}{l}\text { Pneumonia } \\
\text { neonatorum }\end{array}$ & 70 & 26,7 \\
\hline 4 & $\begin{array}{ll}\text { Infeksi } & \text { traktus } \\
\text { urinarius } & \end{array}$ & 6 & 2,3 \\
\hline 5 & Osteitis akut & 2 & 0,8 \\
\hline 6 & $\begin{array}{l}\text { Tetanus } \\
\text { neonatorum }\end{array}$ & 15 & 5,7 \\
\hline \multicolumn{2}{|r|}{ Jumlah } & 206 & 78,6 \\
\hline B & \multicolumn{3}{|l|}{ Infeksi Ringan } \\
\hline 7 & Omfalitis & 38 & 14,5 \\
\hline 8 & $\begin{array}{l}\text { Pemfigus } \\
\text { neonatorum }\end{array}$ & 5 & 1,9 \\
\hline 9 & $\begin{array}{l}\text { Oftalmia } \\
\text { neonatorum }\end{array}$ & 6 & 2,3 \\
\hline 10 & Moniliasis & 3 & 1,1 \\
\hline 11 & Stomatitis & 4 & 1,5 \\
\hline & Jumlah & 56 & 21,4 \\
\hline & Jumlah A+B & 262 & 100 \\
\hline
\end{tabular}

Dari tabel 4 di atas dapat dilihat hampir seluruh $(78,6 \%)$ bayi mengalami infeksi berat. Penyakit tertinggi yang diderita bayi baru lahir adalah sepsis neonatorum sebanyak 38,2\% untuk jenis infeksi berat untuk penyakit dengan jenis 
infeksi ringan adalah 14,5\% omfalitis. Dari tabel 4 juga dapat dilihat bahwa penyakit yang paling sedikit diderita adalah osteitis akut dengan jumlah $2(0,8 \%)$ bayi.

Table 4.

Distribusi Frekuensi Bayi Berdasarkan Cara Keluar di Bagian Perinatologi RSUP Dr. M. Djamil Padang Tahun 2012

\begin{tabular}{|c|l|l|l|}
\hline $\begin{array}{c}\text { N } \\
\text { o }\end{array}$ & \multicolumn{1}{|c|}{$\begin{array}{c}\text { Cara } \\
\text { Keluar }\end{array}$} & $\begin{array}{l}\text { Frekuens } \\
\text { i (n) }\end{array}$ & $\begin{array}{c}\text { Presentas } \\
\text { e (\%) }\end{array}$ \\
\hline 1 & $\begin{array}{l}\text { Dipulangka } \\
\text { n hidup }\end{array}$ & 158 & 60,3 \\
\hline 2 & $\begin{array}{l}\text { Meninggal } \\
\text { di RS }\end{array}$ & 104 & 39,7 \\
\hline \multicolumn{2}{|c|}{ Jumlah } & 262 & 100 \\
\hline
\end{tabular}

Dari tabel 5 di atas dapat dilihat sebagian besar $(60,3 \%)$ bayi yang dirawat dengan penyakit infeksi keluar dari rumah sakit dengan cara dipulangkan hidup dan $39,7 \%$ bayi meninggal di rumah sakit.

A. Gambaran Kejadian Infeksi Berat Bayi Baru Lahir di Bagian Perinatologi RSUP Dr.M.Djamil Padang Tahun 2012

Dari hasil penelitian dapat dilihat, untuk infeksi berat, sepsis neonatorum menempati posisi terbanyak kejadian infeksi (100 bayi) dan osteitis akut dengan jumlah terendah ( 2 bayi). Hasil ini juga sesuai dengan peneltian yang dilakukan di rumah sakit Cipto Mangunkusumo (RSCM) dalam periode Januari-September 2005, angka kejadian sepsis neonatorum sebesar $13,68 \%$ dari seluruh kelahiran hidup dengan tingkat kematian sebesar 14,8\%. Penyebab kematian utama pada neonatus tersebut adalah infeksi, prematuritas dan asfiksia pada bayi baru lahir.

Dari tabel 2 dapat dilihat bahwa jenis kelamin bayi baru lahir yang mengalami infeksi yang dirawat diruangan perinatologi RSUP Dr.M.Djamil Padang dari bulan Januari sampai Desember 2012 adalah lakilaki sebanyak 140 orang $(53,4 \%)$ dan perempuan sebanyak 122 orang $(46,6 \%)$.
Untuk jenis infeksi berat didapatkan 116 bayi laki-laki dan 90 bayi perempuan mengalami kejadian infeksi. Untuk kejadian sepsis neonatorum dengan jenis kelami laki-laki sebanyak 61 bayi dan perempuan sebanyak 39 bayi.

Dari data tersebut dapat dilihat bahwa kejadian penyakit infeksi lebih banyak terjadi pada pasien dengan jenis kelamin laki-laki. Salah satu faktor predisposisi dari penyakit infeksi adalah jenis kelamin lakilaki. Hasil yang didapat pada penelitian ini sesuai dengan penelitian yang telah dilakukan oleh Willar, dkk pada tahun 2010 sejak bulan Januari-Agustus 2009 di bangsal neonatus RSU Prof.Dr.R.D.Kandou, Manado yaitu dari 36 responden didapatkan 19 orang (53\%) dengan jenis kelamin laki-laki dan 17 orang (47\%) dengan jenis kelamin perempuan (Willar, dkk, 2010 :54).

Dari hasil penelitian terlihat angka kejadian infeksi berat sangat tinggi terjadi pada bayi dengan berat badan lahir tidak normal. Dari 100 bayi dengan sepsis neonatorum, 48 bayi lahir dengan berat badan lahir normal dan 52 bayi dengan berat badan lahir tidak normal (BBLR, BBLSR dan makrosomia). Disini terlihat, kejadian infeksi berhubungan dengan berat badan lahir bayi. Oleh sebab itu, bayi dengan berat badan lahir rendah harus diperhatikan oleh tenaga kesehatan dalam melakukan tindakan kepada bayi agar dapat meningkatkan upaya pencegahan infeksi.

Selain itu, prosedur invasif juga merupakan salah satu faktor penting terjadinya infeksi. Prosedur invasif termasuk faktor eksogen yaitu faktor dari luar penderita (Hasbullah, 1993 dalam Harianto 2009). Dari penelitian didapatkan prosedur invasif pada bayi baru lahir dengan penyakit infeksi di ruangan perinatologi RSUP Dr.M.Djamil Padang dari bulan Januari sampai Desember 2012 dapat dilihat pada tabel 2, yaitu pada 81 orang pasien $(30,9 \%)$ dilakukan prosedur invasif dan 181 orang $(59,1 \%)$ tidak dilakukan prosedur invasif. Untuk jenis infeksi berat, pada 71 bayi dilakukan 
prosedur infvasif dan pada 135 bayi tidak dilakukan prosedur invasif. Untuk bayi dengan sepsis neonatorum, 38 bayi dilakukan prosedur invasif dan 62 bayi tidak dilakukan prosedur invasif.

Dari hasil penelitian dapat dilihat kebanyakan bayi lahir dengan lama ketuban pecah normal dan dapat disimpulkan dalam penelitian ini KPD tidak terlalu berpengaruh terhadap kejadian infeksi berat yang terjadi di RSUP Dr.M.Djamil Padang tahun 2012 . Dari penelitian didapatkan ketuban tidak berwarna dan tidak berbau (normal) sebanyak 173 orang (66\%), dan 89 orang $(34 \%)$ dengan ketuban berwarna dan berbau (tidak normal). Untuk kejadian infeksi berat, 138 bayi dengan ketuban normal (tidak berwarna dan berbau) dan 68 bayi dengan ketuban berwarna dan berbau (tidak normal). Pada kejadian sepsis neonatorum, 74 bayi dengan warna dan bau ketuban normal dan 26 bayi dengan warna dan bau ketuban tidak normal. Jadi kejadian infeksi kebanyakan terjadi pada bayi dengan keadaan ketuban tidak berwarna dan tidak berbau (normal), namun angka kejadian pada bayi dengan ketuban tidak normal juga terlihat cukup tinggi (34\%), sehingga dapat mempengaruhi terjadinya infeksi pada bayi.

Berdasarkan hasil penelitian juga didapatkan, bayi baru lahir dengan penyakit infeksi di ruangan perinatologi RSUP Dr.M.Djamil Padang dari bulan Januari sampai Desember 2012 sebanyak 158 orang $(60,3 \%)$ bayi keluar dengan cara dipulangkan dalam keaddaan hidup dan 104 orang $(39,7 \%)$ dalam keadaan meninggal. Untuk kejadian infeksi berat, 105 bayi keluar dengan cara dipulangkan hidup dan 101 bayi dalam keadaan meninggal. Untuk penyakit sepsis neonatorum, 50 bayi dipulangkan hidup dan 50 bayi keluar dalam keadaan meninggal. Dari hasil ini dapat dilihat bahwa infeksi berat pada bayi baru lahir merupakan penyebab kematian tertinggi pada bayi baru lahir dengan penyakit infeksi. Karena angka kematian ini sangat tinggi ini, sangat diharapkan dilakukannya upaya untuk menurunkan tingkat mortalitas pada bayi tersebut.

Dari hasil penelitian dapat disimpulkan untuk bayi yang mengalami infeksi berat sebagian besar terjadi pada bayi dengan usia $<8$ hari dengan jenis kelamin laki-laki, hampir setengah bayi dengan berat badan lahir rendah, dan terjadi pada hampir setengah bayi yang dilakukan prosedur invasif. Untuk karakteristik bayi berdasarkan karakteristik ibu, kejadian infeksi berat terjadi pada hampir setengah bayi dengan usia gestasi preterm, sebagian kecil pada bayi dengan ketuban pecah dini (KPD) dan hampir setengah bayi dengan warna dan bau ketuban tidak normal. Dari semua bayi yang mengalami infeksi berat hampir setengah bayi dipulangkan dalam keadaan meninggal di rumah sakit.

Untuk kejadian sepsis neonatorum dapat disimpulkan terjadi pada sebagian besar bayi dengan usia $<8$ hari, sebagian besar dengan jenis kelamin laki-laki, sebagian besar bayi dengan BBLR dan BBLSR, hampir setengah bayi yang dilakukan prosedur invasif, hampir setengah bayi dengan usia gestasi preterm, sebagian kecil dengan KPD, dan pada hampir setengah bayi dengan dengan warna dan bau ketuban tidak normal. Setengah dari bayi dengan sepsis neonatorum ini keluar dari rumah sakit dengan keadaan meninggal.

B. Gambaran Kejadian Infeksi Ringan Bayi Baru Lahir di Bagian Perinatologi RSUP Dr.M.Djamil Padang Tahun 2012

Dari hasil penelitian diperoleh umur bayi yang mengalami infeksi ringan yaitu 37 bayi $<8$ hari dan 19 bayi berumur 8-28 hari. Untuk penyakit omfalitis, umur bayi $<8$ hari sebanyak 31 bayi dan 7 bayi dengan umur 8-28 hari. Hal ini juga didukung oleh penelitian Tiflah, 2004 yang menunjukkan dari 97 sampel, sebagian besar penderita berusia $<7$ hari yakni sebesar $(86,6 \%)$. 
Dari hasil penelitian dapat dilihat sebagian besar $(66 \%)$ bayi berusia $<8$ hari untuk kejadian infeksi ringan dan untuk kejadian omfalitis sebagian besar (81\%) bayi berusia $<8$ hari. Penyakit infeksi dapat terjadi pada semua tingkat usia, namun kalangan usia muda lebih rentan karena pertahanan tubuh yang rendah dan sistem imunitas tubuh yang belum berkembang sempurna (Orteza, 1999). Dapat disimpulkan semakin kecil usia bayi, semakin mudah bayi tersebut mengalami infeksi.

Berdasarkan jenis kelamin, 24 bayi dengan kejadian infeksi ringan berjenis kelamin laki-laki dan 32 bayi berjenis kelamin perempuan. Untuk penyakit omfalitis, 17 bayi dengan jenis kelamin laki-laki dan 21 bayi dengan jenis kelamin perempuan.

Hal ini berbeda dengan penelitian Simbolon tahun 2008 (dalam Sari, 2010) dengan menggunakan desain penelitian kasus kontrol di RSUD Curup kabupaten Rejang Lebong Bengkulu menyebutkan bahwa menurut faktor bayi, kejadian infeksi banyak terjadi pada bayi laki-laki $(61,2 \%)$. Jadi, pada penelitian ini $42 \%$ infeksi ringan terjadi pada bayi laki-laki dan untuk omfalitis 30\% terjadi pada bayi laki-laki. Dari penelitian ini dapat disimpulkan, jenis kelamin laki-laki tidak berpengaruh terhadap kejadian infeksi ringan pada bayi baru lahir.

Menurut berat badan lahir, terlihat 49 bayi dengan berat badan lahir normal, 5 bayi dengan berat badan lahir rendah (BBLR), 1 bayi dengan berat badan lahir sangat rendah (BBLSR), 1 bayi dengan makrosomia. Untuk jenis penyakit omfalitis, 34 bayi dengan berat badan normal, 3 bayi dengan BBLR, 1 bayi dengan BBLSR, dan tidak ada bayi dengan makrosomia. Berat badan lahir juga merupakan salah satu faktor predisposisi terjadinya penyakit infeksi pada bayi baru lahir. Jadi semakin kecil berat badan lahir bayi, semakin mudah terjadi infeksi karena kematangan organ yang belum sempurna.
Namun, hal ini tidak ditunjukkan pada kejadian infeksi ringan ini.

Dari penelitian juga didapatkan data pada 10 bayi dilakukan prosedur invasif dan 46 bayi tidak dilakukan prosedur invasif. Pada penyakit omfalitis, dilakukan prosedur invasif pada 5 bayi dan tidak dilakukan prosedur invasif sebanyak 33 bayi. Prosedur invasif merupakan salah satu faktor penting terjadinya infeksi. Prosedur invasif termasuk faktor eksogen yaitu faktor dari luar penderita (Hasbullah, 1993). Namun, dalam penelitian ini, prosedur invasif tidak terlalu berpengaruh terhadap kejadian infeksi ringan karena hasil penelitian metunjukkan sebagian kecil bayi yang dilakukan prosedur invasif yang mengalami infeksi ringan.

Untuk usia gestasi ibu bayi dengan infeksi ringan, 4 bayi dengan preterm, 48 bayi aterm, dan 4 bayi dengan posterm. Pada bayi penderita omfalitis, 3 bayi dengan usia gestasi preterm, 35 bayi dengan aterm, dan tidak ada bayi dengan posterm. Jadi, untuk kejadian infeksi ringan pada penelitian ini tidak terlalu dipengaruhi oleh usia gestasi ibu. Menurut Pusponegoro (2000), prematuritas dan berat lahir rendah, merupakan faktor resiko untuk terjadinya infeksi pada neonatus disebabkan fungsi dan anatomi kulit yang masih imatur, dan lemahnya sistem imun.

Hasil penelitian juga menunjukkan 50 bayi dengan lama ketuban pecah normal dan 6 bayi dengan ketuban pecah dini (KPD). Untuk bayi dengan omfalitis, lama ketuban pecah normal sebanyak 34 bayi dan 4 bayi dengan KPD. KPD merupakan faktor risiko utama prematuritas yang merupakan penyumbang utama penyakit infeksi dan kematian perinatal. Namun pada kejadian infeksi ringan dan omfalitis ini, KPD tidak begitu berpengaruh terhadap kejadian infeksi karena kebanyakan kasus terjadi pada lama ketuban pecah normal.

Warna dan bau ketuban juga dapat dilihat dari penelitian ini. Tiga puluh lima bayi dengan ketuban normal (tidak berwarna dan berbau) dan 21 bayi dengan ketuban tidak normal (berwarna dan 
berbau). Untuk kejadian omfalitis, 30 bayi dengan ketuban normal dan 8 bayi dengan ketuban berwarna dan berbau (tidak normal). Dalam penelitian Nugrahani, dkk tahun 2005 dengan menggunakan rancangan penelitian uji diagnostik potong lintang di RS Dr. Sardjito Yogyakarta terdapat proporsi ibu dengan keadaan air ketuban keruh melahirkan bayi yang mengalami infeksi sebanyak 33,1\%. Dari penelitian dapat dilihat sebagian besar bayi yang mengalami infeksi dengan warna dan bau ketuban normal dan terlihat warna dan bau ketuban berperngaruh sebagai penyebab terjadinya infeksi ringan pada bayi baru lahir di bagian perinatologi RSUP DR.M.Djamil Padang pada tahun 2012.

Untuk bayi dengan jenis infeksi ringan dapat diketahui cara keluar bayi dari rumah sakit dengan cara dipulangkan hidup sebanyak 53 bayi dan 3 bayi meninggal di rumah sakit. Untuk kejadian omfalitis, 35 bayi dipulangkan dalam keadaan hidup dan 3 bayi meninggal di rumah sakit. Pada jenis infeksi ini, terlihat angka kematian yang rendah. Dan diharapkan angka kematian ini dapat dihilangkan.

Dari hasil penelitian dapat disimpulkan, untuk kejadian infeksi ringan sebagian besar terjadi pada bayi dengan usia $<8$ hari, sebagian besar terjadi pada bayi perempuan, sebagian besar pada bayi dengan berat badan lahir normal, dan terjadi pada sebagian besar bayi yang tidak dilakukan prosedur invasif. Untuk karakteristik bayi berdasarkan karakteristik ibu, sebagian besar terjadi pada bayi dengan usia gestasi normal, sebagian kecil bayi dengan ketuban pecah dini, hampir setengah bayi dengan warna dan bau ketuban tidak normal. Hampir seluruh bayi dengan infeksi ringan keluar dari rumah sakit dengan cara dipulangkan dalam keadan hidup.

Untuk kejadian omfalitis, sebagian besar terjadi pada bayi berumur $<8$ hari, sebagian besar pada bayi dengan jenis kelamin perempuan, hampir seluruh dengan berat badan lahir normal, pada hampir seluruh bayi yang tidak dilakukan prosedur invasif, dan pada sebagian kecil bayi dengan usia gestasi preterm, sebagian kecil bayi dengan KPD, dan pada sebagian kecil bayi dengan warna dan bau ketuban tidak normal. Hampir seluruh bayi yang dirawat dengan infeksi ringan dipulangkan dengan keadaan hidup.

\section{KESIMPULAN DAN SARAN}

Berdasarkan hasil dari penelitian yang telah dilakukan mengenai gambaran penyakit infeksi bayi baru lahir di ruangan perinatologi RSUP Dr. M. Djamil Padang Tahun 2012, maka dapat diambil kesimpulan sebagai berikut:

1. Hampir seluruh $(78,6 \%)$ bayi mengalami infeksi berat

2. Sebagian kecil $(21,4 \%)$ bayi mengalami infeksi ringan

Bagi ibu bayi dapat mengatur pola makan sehat dan bergizi dalam jenis dan jumlah yang cukup pada ibu untuk mempertahankan daya tahan tubuh sehingga terhindar dari penyakit infeksi. Selain itu disarankan kepada ibu untuk meningkatkan pengetahuan ibu tentang pentingnya pemeriksaan saat hamil (Antenatal Care) dengan cara mencari informasi melalui buku, televisi atau media massa lainnya. Bagi tenaga kesehatan, menyarankan ibu untuk melakukan pemeriksaan antenatal (antenatal care) secara teratur untuk mencegah terjadinya persalinan prematur atau berat badan lahir rendah yang sangat rentan terkena penyakit infeksi

\section{DAFTAR PUSTAKA}

Abdel-Fattah, AM Youssr. 2005. Epidemology, Clinic and Prognostic Profil Acute Bacterial Meningitis Among Children In Alexandria, Egypt. India Journal of Medical Microbiology

Aminullah A. Sepsis Pada Bayi Baru Lahir. Dalam: M. Sholeh Kosim, Ari Yunanto. dkk (editor). 2008. Buku 
Ajar Neonatologi. Jakarta: Ikatan Dokter Anak Indonesia

Arikunto, S. 2005. Prosedur Penelitian Suatu Pendekatan Praktek. Jakarta: Rineka Cipta.

Asih, Langgeng Setyo. 2009. Hubungan Hasil Pemeriksaan Makroskopis Dan Mikroskopis Urin Tersangka Infeksi Traktus Urinarius Di Laboratorium Klinik Bina Sehat. Skripsi Universitas Muhammadiyah, Semarang.

Bobak, M. Irene, et al. 2005. Buku Ajar Keperawatan Maternitas, edisi 4. Alih bahasa: Maria A. Wijayarini. Jakarta: EGC

Depkes RI, 2007. Penatalaksanaan sepsis neonatoum.

http://www.depkes.go.id/. Diakses tanggal 24 Oktober 2012.

Dini, Nintya Zeina. 2009. Prevalensi Meningitis Pada Pasien Rawat Inap Di Rumah Sakit Umum Pusat Fatmawati Jakarta Pada Bulan Agustus 2006 Sampai Juli 2009. Skripsi program studi pendidikan dokter, UIN Syarifhidayatullah Jakarta.

Efriza, 2007. Determinan kematian neonatal dini di RSUD Dr Ahmad Mochtar Bukittinggi. Jurnal kesehatan masyarakat nasional volume 2 nomor 3

Fatima, et al. 2011. Incidence and etiology of omphalitis in Pakistan: a community-based cohort study. J Infect Dev Ctries 2011; 5(12):828833.

Hantamian, MD and Fahimzad, MD. 2009. Epidemology Aseptic meningitis in Pediatrics. Evaluation and Cerebrospinal Fluid Changes. Iran J. Child Neurology.

Harianto A. 2009. Sepsis Neonatorum. SMF Ilmu Kesehatan Anak, Fakultas Kedokteran UNAIR Surabaya. Accessed Maret 2013. Available from URL http://www.pediatrik.com/isi03.php ?page $=$ html \&hkategori $=$ pdt $\&$ direkt ori $=$ pdt \&filepdf $=0 \& p d f=\& h t m l=07$ 110-tsyz266.htm

Harsono. 2005. Buku Ajar Neurologi Klinis. Perhimpunan Dokter Spesialis Saraf Indonesia. Cetakan ketiga. Yogyakarta: Gadjah Mada University Press

Hayati, N, 2009. Merawat tali pusat, from file:///D:perawatan\%20tali\%pusat.htm.

Herlina, Novia, 2010. Pengetahuan Ibu Postpartum Tentang Infeksi Tali Pusat Di Wilayah Kerja Puskesmas Rawat Inap Kota Baru Dan Pulau Kijang, Kecamatan Keritang Inhil Riau Tahun 2009. Skripsi. Repository USU

Israr, Yayan A. 2008. Meningitis. Faculty of Medicine - University of Riau, Arifin Achmad General Hospital of Pekanbaru.

Jumah. 2007. Tetanus: a review of the literature. $\mathrm{Br}$ : JAnaesth

Kasim, M. Sholeh. 2006. Gawat Darurat Neonatus pada Persalinan Preterm. Sari Pediatri, Vol. 7, No. 4, Maret 2006: 225 - 231

Kasim, M. Sholeh. 2009. Infeksi Neonatal Akibat Air Ketuban Keruh. Sari Pediatri, Vol. 11, No. 3, Oktober 2009.

Lewis MAO, Lamey PJ. 1998 Tinjauan klinis penyakit mulut. Jakarta: Widya Medika;

Manuaba, I.B.G, 1998. Ilmu kebidanan, penyakit kandungan dan KB. Jakarta: EGC Mayetty, dkk. 2010. Kolonisasi kuman dan kejadian omfalitis pada tiga regimen perawatan tali pusat pada bayi baru lahir. Sari Pediatri, Vol. 11, No. 5, Februari 2010

Mochtar R. 1998. Sinopsis Obstetri Edisi I : "Ketuban Pecah Dini", Jakarta : Penerbit Buku Kedokteran EGC

Mullany LC, Darmstat GL, Tielsch JM. Role of antimicrobial applications to the umbilical cord in neonates to prevent bacterial colonization and infection: a review of the evidence. Pediatr infect Dis J 2003;22:9961002. 
Musbikin. 2006. Persiapan Menghadapi Persalinan. Yogyakarta. Mitra Pustaka

Negara, Naufal Sastra, dkk. 2009. Ketuban Pecah Dini dan Demam Intrapartum Sebagai Faktor Risiko Sepsis Neonatorum Onset Dini. Sari Pediatri, Vol. 10, No. 5, Februari 2009

Notoatmodjo, Soekidjo. (2005). Metodologi Penelitian Kesehatan. Jakarta: PT Rineka Cipta

Nugrahani, dkk. 2005. Proporsi bayi dengan kejadian sepsis neonatorum di RS Dr. sardjito Yogyakarta tahun 2004. Repository

Nursalam. 2008. Konsep dan penerapan metodologi penelitian ilmu keperawatan. Surabaya: Salemba Medika

Orteza G, Bitanga ES. 2002. Tuberculous meningitis: neuroepidemiology, clinical features and outcome among adult cases at UPPGH Medical Center from 1990-1999

Panduan penatalaksanaan IDAI. 2010. Tetanus neonatorum dalam kepanitraan Klinik Ilmu penyakit anak periode 7 Februari 2011

Prawirohardjo, Sarwono. 2008. Ilmu Kebidanan. Jakarta: Yayasan Bina Pustaka Sarwono Prawirarjo.

Pusponegoro, Titut S. 2000. Sepsis pada neonatus. Dalam Sari pediatri Vol. 2, No. 2, Agustus 2000: 96 -102

Rangkuti, S. 2011. Pengaruh Perawatan Tali Pusat Dengan Memakai Kasa Alkohol 70\% Dan Kasa Kering Terhadap Waktu Putusnya Tali Pusat. Skripsi. Repository USU

Riskesdas. 2007. Penyebab kematian bayi di Indonesia: diakses tanggal 27 Oktober 2012 http://www.infodokterku.com/index .php

Rizkianti, Annisa. 2009. Faktor-Faktor yang Berhubungan Dengan Kejadian Pneumonia Pada Balita 10-59 bulan yang Dirawat Inap Di RSUP Persahabatan Jakarta Tahun 2008. Skripsi Program studi ilmu kesehatan masyarakat, Universitas Indonesia, Depok.

Rocky, Willar, dkk. 2010. Jumlah Trombosit dan Mean Platelet Volume Sebagai Faktor Prognosis pada Sepsis Neonatorum. Sari Pediatri, Vol. 12, No. 1, Juni 2010

Sari, Ira Mulya. 2010. Faktor - Faktor Risiko Prenatal Dan Neonatal Yang Berhubungan Dengan Kejadian Infeksi Tali Pusat Di Ruang Neonatus Risiko Tinggi Irna D Anak RSUP Dr. M. Djamil Padang Tahun 2010. Repository.unand.ac.id Staf Pengajar Ilmu Kesehatan Anak FKUI. 2007. Ilmu kesehatan anak. Jakarta: Bagian Ilmu Kesehatan Anak FKUI

Subanada, Ida Bagus dan Ni Putu Siadi Purniti. 2010. Pneumonia pada Anak. Sari Pediatri, Vol. 12, No. 3, Oktober 2010

Sumaryani, Sri. 2006. Perbedaan waktu pelepasan tali pusat dan kejadian omphalitis pada perawatan tali pusat dengan Asi, Alkohol 70\%, dan kering terbuka. http:// lontar.ui.ac.id/opac/themes/libri2/de tail.jsp

Suryani, Emy, dkk. 2006. Metode perawatan tali pusat bayi baru lahir dengan kassa basah alkohol $70 \%$ dan perawatan kassa steril. Jurnal Prospect, tahun 2, nomor 3

Suwiyoga, K, dkk, $2007 . \quad$ Peran Korioamnionitis Klinik, Lama Ketuban. Pecah, dan Jumlah Periksa Dalam pada Ketuban Pecah Dini. Kehamilan Aterm terhadap insiden sepsis neonatorum dini. Cermin dunia kedokteran

Tambunan, Eviana, S. 2008. Hubungan berqat badan lahir bayi dengan infeksi nosokomial di ruang perinatologi. Medika : Jurnal Kedokteran Indonesia Vol. 34 No. 6 (Jul. 2008)

Tiflah. 2004. Bakteremia Pada Neonatus: Hubungan Pola Kuman Dan KepekaanTerhadap Antibiotik 
Inisial Serta Faktor Risikonya Di Bangsal Bayi Risiko Tinggi (BBRT) RS.Dr.Kariadi Tahun 2004. Skripsi Fakultas Kedokteran Universitas Diponegoro

Wilar, dkk. 2010. Faktor risiko sepsis awitan dini. Sari Pediatri, Vol. 12, No. 4, Desember 2010

Wong, L Donna. 2003. Pedoman Klinis Keperawatan Pediatrik. Jakarta: Penerbit Buku Kedokteran EGC

Wikipedia. Omphalitis. http://en.wikipedia.org/wiki/Ompha litis. diakses tanggal 8 November 2012

Yulidar, H, dkk. 2006. Pola Kuman, Sensitifitas Antibiotik dan Risiko Kematian oleh Kuman Staphylococcus coagulase Negatif pada Sepsis Neonatorum di RS DR Moewardi Surakarta. Sari Pediatri, Vol. 8, No. 2, September 2006: 122 $-126$

Zupan, J, dkk. 2004. Topical umbilical cord care at birth. The Cochrane Collaboration, issue 3 . 